\title{
Morphological Development of Larvae and Juveniles of Acanthopagrus schlegeli
}

\author{
Chung-Bae Kang ${ }^{1}$, Sung-Hoon Lee ${ }^{2}$, Jae-Ho Hwang ${ }^{2}$ and ${ }^{\dagger}$ Kyeong-Ho Han ${ }^{2}$ \\ ${ }^{1}$ Korea Ocean and Fisheries Institute, Busan 608-810, Korea \\ ${ }^{2}$ Dept. of Aqualife Science, Chonnam National University, Yeosu 550-749, Korea
}

\begin{abstract}
Newly hatched black porgy larvae (Acanthopagrus schlegeli) swam to the surface, with the mouth and anus still closed and were 1.90-2.11 mm (mean, $2.0 \mathrm{~mm}$ ) in total length (TL). The larvae were 2.71-2.94 mm TL (mean, $2.82 \mathrm{~mm}$ ) on day 2 after hatching. At this time, about two-thirds of the yolk was absorbed, the bladder and intestines had formed, and the mouth and anus were open. Total length was 4.32-4.66 mm (mean, $4.45 \mathrm{~mm}$ ) at the post-larval stage on days 5-6 after hatching, and the yolk and oil globule were almost absorbed. The end of the notochord began to flex, and 6-8 caudal fin rays were visible. The larvae were $15.37-16.1 \mathrm{~mm}$ TL (mean, $15.83 \mathrm{~mm}$ ) at the juvenile stage on days $30-32$ after hatching, and the number of rays in all fins was completely revealed.
\end{abstract}

Key words : Acanthopagrus schlegeli, Black porgy, Morphological development, Larva

\section{INTRODUCTION}

Acanthopagrus schlegeli, commonly known as black porgy or black sea bream, belong to the family Sparidae in the order Perciformes, and live in coastal waters. Black porgy are estuarine fish found in shallow $(\leq 50 \mathrm{~m})$, sandy, or rocky coastal waters with algal growth and are widely distributed in coastal areas of Korea, southern Japan, south of Hokkaido, Ryukyu, the southeastern China Sea, and Taiwan (Chyung, 1977). They are sedentary fish but move to deeper water in winter. Their spawning season is May July; they spawn on shallow gravel, sandy seabed, or on tidal flats with relatively complex seabed topography (Kim et al., 2004; Okamura \& Amaoka, 1997).

Black porgy were an aquaculture candidate in the late 1980s and seedling production has been investigated (Lee \& Rho, 1987). In particular, black porgy have attracted attention as a release target species and were the main species targeted for marine ranching on the Jeonnam archipelago in 2002.

Early life and growth (Seno, 1912; Oshim, 1942) of larvae and juveniles (Mito, 1957), morphological development of larvae and juveniles (Fukuhara, 1977), and morphological development of larvae and behavioral patterns during early life have also been studied (Fukuhara, 1987). Studies in South Korea include development of the digestive tract (Lee et al., 2000), early adaptation of released juveniles (Yoo et al., 2003), comparison of body components (Ji et al., 2004), early feeding patterns and body-component changes in released juveniles (Ji et al., 2007), morphological changes

\footnotetext{
Manuscript received 12 December 2014, Received in revised form 18 December 2014, Accepted 19 December 2014

${ }^{\dagger}$ Corresponding Author : Kyeong-Ho Han, Dept. of Aqualife Science, Chonnam National University, Yeosu 550-749, Korea. Tel. : +82-61-659-7163, Fax : +82-61-659-7169, E-mail : aqua05@chonnam.ac.kr

This is an Open Access article distributed under the terms of the Creative Commons Attribution Non-Commercial License (http:/l creativecommons.org/licenses/by-nc/3.0) which permits unrestricted non-commercial use, distribution, and reproduction in any medium, provided the original work is properly cited.
} 
in the spinal cord (Park et al., 2008), and behavioral characteristics (Kang et al., 2008). However, no study has investigated the life cycle of $A$. schlegeli, except one study on the early life history conducted by Kim (1970) regarding the characteristics of spawned eggs and newly hatched larvae.

In this study, we investigated the early life history of $A$. schlegeli inhabiting the Korean southern coast and determined the criteria for classifying larvae and juveniles by observing morphological development of newly hatched larvae.

\section{MATERIALS AND METHODS}

We harvested brood-stock for the lab experimets using an elongated mesh net in the coastal region around Yeosusi Dolsan (Fig. 1) in May 2007 and transported the fish to

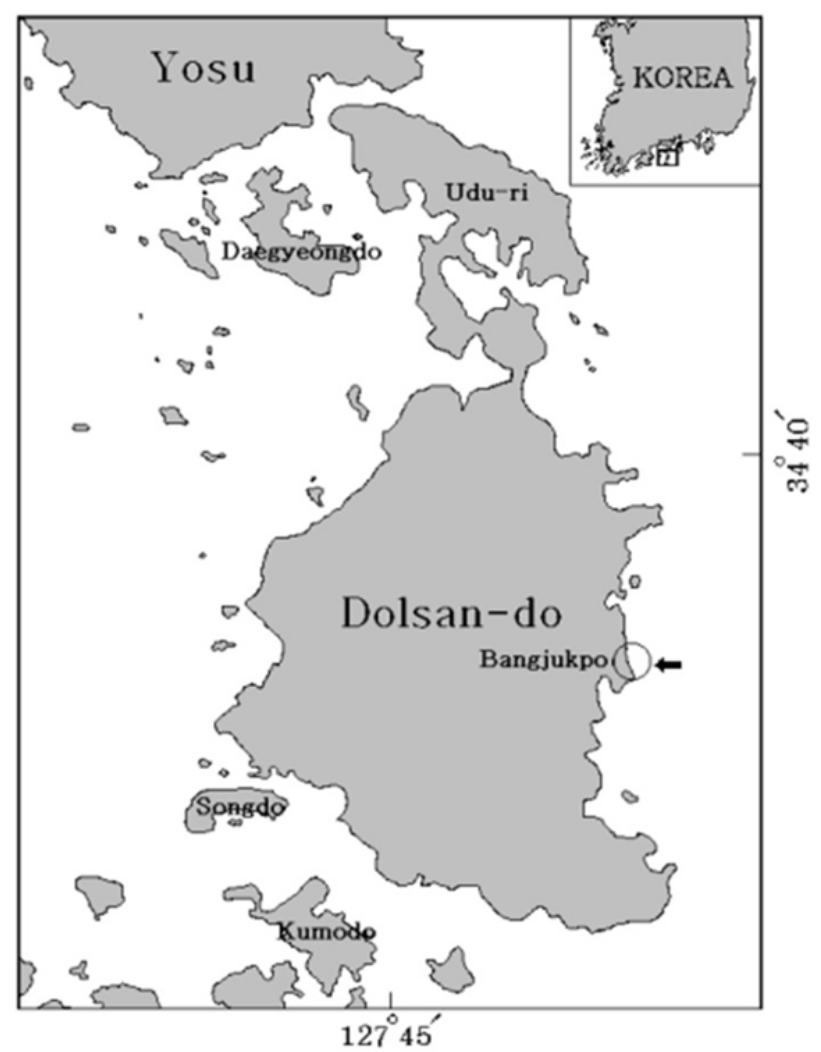

Fig. 1. Map showing the adult Acanthopagrus schlegeli sampling area in Dolsan-do, Korea. the Resource Biology Laboratory of Jeonnam University. Eggs were obtained from sexually mature females (measured data), and the eggs were artificially inseminated using the dry method on May 11, 2007.

Some of the hatched larva were kept in a transparent tank $(30 \times 40 \times 90 \mathrm{~cm})$ to observe morphological changes from day 1 after hatching to the juvenile stage. We maintained the remaining fish in a larval rearing tank filled with filtered seawater to investigate survival rate and growth.

Water temperature was measured at 5 day intervals starting from the first day of the experiment. The interval was reset each month, so the first day of the new month was the beginning of the new 5-day interval. Rearing water was maintained at $20.5-21.5^{\circ} \mathrm{C}$ (mean, $21.9^{\circ} \mathrm{C}$ ). After stabilizing the rearing water with condensed chlorella paste (Chlorella sp.), hatched larvae were fed rotifers (Brachionus plicatilis), and subsequently Artemia sp. and mixed feed (Fig. 2).
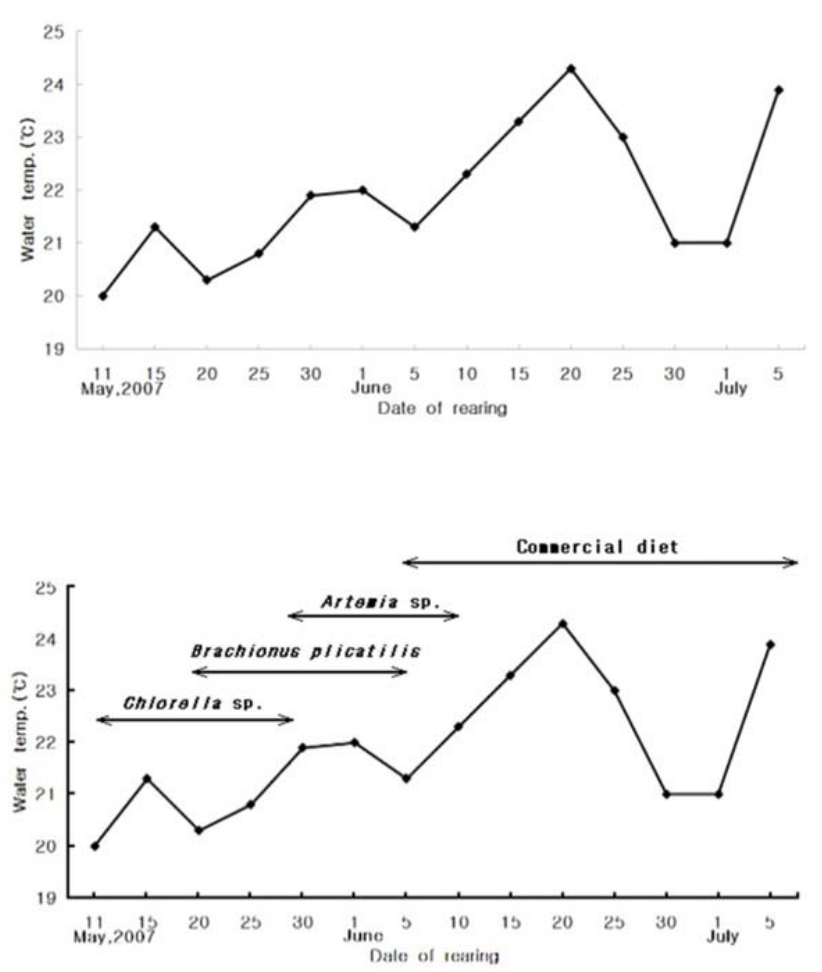

Fig. 2. Daily water temperature variation during Acanthopagrus schlegeli larval and juvenile development. 
Morphological development at each growth stage was sketched while observing randomly harvested individuals $(\mathrm{n}=10)$ daily from the first day after hatching. Each individual was anesthetized with ice or MS-222 (tricaine methanesulfonate; Sandoz, Basel, Switzerland), and each body part was observed under a stereo microscope (Nikon, SMZ-100; Tokyo, Japan) and a universal projector (Nikon, $\mathrm{V}-12 \mathrm{~B})$. Each body part was measured to an accuracy of $0.01-\mathrm{mm}$, and the larval growth stage was defined according to Okiyama (1988).

\section{RESULTS}

\section{Larvae}

Newly hatched larvae were 1.90-2.11 mm (mean, 2.04 $\mathrm{mm}$ ) in total length (TL). They carried a yolk-sac, swam at the surface with their mouth closed, the head was smaller than the trunk, and the tail was compressed. Black pigment spots were densely distributed around the eyes and the center of the caudal region. A total of 20-22 myomeres were detected $(6 \leq n \leq 8+14)$ (Fig. 3A).

The larvae had grown to 2.71-2.94 mm TL (mean, 2.82 $\mathrm{mm}$ ) on day 2 after hatching, with about two thirds of the yolk absorbed, a formed bladder and intestines, and mouth and anus open. The pectoral fins developed first among all fins. The eyes, yolk, and oil globule were pigmented black, and the black pigment spots in the caudal region began to scatter. At this time, 22-24 myomeres were detected ( $7 \leq \mathrm{n}$ $\leq 9+15)$ (Fig. 3B).

Total larval length was $2.96-3.24 \mathrm{~mm}$ (mean, $3.05 \mathrm{~mm}$, $\mathrm{n}=10$ ) on days $3-4$ after hatching, but the yolk and oil globule had not yet completely absorbed. The eyes turned completely black, and dense black pigment spots appeared in the margins of the dorsal and ventral portions of the digestive tract, flexed regions, and ventral portion of the yolk. The dense black pigment spots that formed previously in the caudal region disappeared and were now ventrally aligned along the trunk. The number of myomeres increased to $25-26(5$ or $6+20)$ (Fig. $3 \mathrm{C})$.

\section{Post-larvae}

Total larval length was 4.32-4.66 mm (mean, $4.45 \mathrm{~mm}$, $\mathrm{n}=10$ ) at the post-larval stage on days 5-6 after hatching, with the yolk and oil globule almost absorbed. Caudal fin rays $(n=6-8)$ were visible, and the end of the notochord began to flex. Black pigment spots were scattered over the head posteriorly and appeared between the ventral myomeres forming a pigmented line (Fig. 3D).

Total larval length was 5.55-6.03 mm (mean, $5.75 \mathrm{~mm}$, $\mathrm{n}=10$ ) on days $8-9$ after hatching. Rays had formed in the pectoral fin, the bases of the pectoral and ventral fins appeared, and the number of caudal fin rays increased to 15. Black pigment spots were scattered over the head anteriorly and superiorly and became darker around the digestive tract (Fig. 3E).

Total larval length was $6.85-7.20 \mathrm{~mm}$ (mean, $7.02 \mathrm{~mm}$, $\mathrm{n}=10$ ) on days 16-18 after hatching. Fins that had been membranous in the larval stage became slender and clear in the parts where the dorsal and anal fins would form. The numbers of pectoral and caudal fin rays increased to 7 and 15 , respectively, and eight rays appeared in each of the dorsal and anal fins. The end of the notochord reached complete flexion of $45^{\circ}$. The number of black pigment spots decreased slightly dorsally and ventrally around the digestive tract and those on the snout and top of the head tended to be dispersed widely. The melanophores on the base of the anal fin disappeared and remained only ventrally on the caudal peduncle. Spines that formed in the opercular area continued to grow, and new melanophores were deposited at the end of the notochord (Fig. 3F).

Total fish length was 8.85-9.25 mm (mean, $9.09 \mathrm{~mm}, \mathrm{n}$ $=10$ ) on days 20-22 after hatching. The membrane-shaped fins disappeared completely, and the dorsal, anal, and caudal fins took their respective forms. The dorsal fin had 
10 spines and 11 rays, the anal fin had two spines and nine rays, and the caudal fin had $17(8+9)$ rays. The ventral fin began to differentiate. Melanophores were deposited in the head posteriorly and on the operculum superiorly and were densely spread along the trunk midline down to half of the spinous dorsal fin. Black pigment spots were scattered along the center of the caudal peduncle (Fig. 3G).

Total fish length was $9.27-10.01 \mathrm{~mm}$ (mean, $9.67 \mathrm{~mm}$, $\mathrm{n}=10$ ) on days $23-25$ after hatching, with an increase in body height. The pectoral fin was elongated around the center to form a rhombus shape, and the ventral fin elongated considerably. The dorsal fin formed notches between the spinous and soft parts, and the caudal fin took a slightly concave form in the center part of the posterior margin. Black pigment spots were dispersed ventrally across the trunk from the occipital crest and snout to the pectoral and anal region, as well as dorsally around the region between the first and fifth spines. The black pigment spots on the caudal peduncle intensified considerably (Fig. 3H). The post-larvae were now in the transition stage, as the number of soft rays reached the final count.

\section{Juveniles}

The juveniles had grown to a TL of $15.37-16.11 \mathrm{~mm}$ (mean, $15.83 \mathrm{~mm}, \mathrm{n}=10$ ) on days $30-32$ after hatching, with the spinous part of the dorsal and anal fins elongated, and the caudal fin becoming concave. Nodes formed in the fin rays except for that of the ventral fin. Each fin had reached its full ray count, with dorsal fin IX (X), 11(10), anal fin III, 9, pectoral fin 15, and ventral fin, I 5; thus, completing growth into a juvenile. Black pigmented spots formed stripes across the body in clusters of 5-7 spots (Fig. $3 I)$.

Juveniles were 15.97-16.83 mm TL (mean, $16.58 \mathrm{~mm}$, n $=10$ ) on days 34-36 after hatching. The black pigment spots around the snout darkened further and were scattered around the dorsal and anal membrane fins, and were
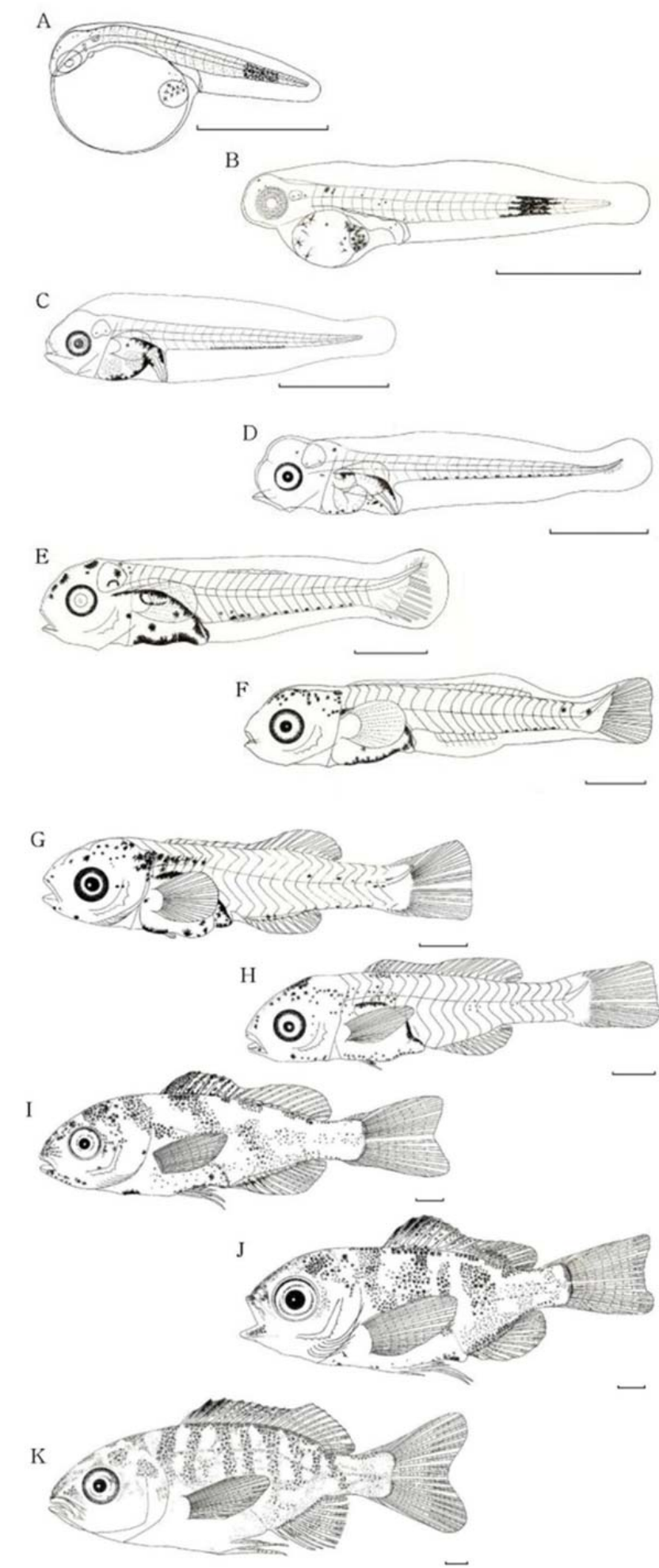

Fig. 3. Acanthopagrus schlegeli larval and juvenile development stages. A: Newly hatched prelava, mean $2.04 \mathrm{~mm}$ total length (TL); B: 2 days after hatching, mean $2.82 \mathrm{~mm}$ in TL; C: 3-4 days after hatching, 
mean $3.05 \mathrm{~mm}$ TL; D: 5-6 days after hatching, mean $4.45 \mathrm{~mm}$ TL; E: $8-9$ days after hatching, mean $5.75 \mathrm{~mm}$ TL; F: 16-18 days after hatching, mean $7.02 \mathrm{~mm}$ TL. Scale bars $=1.0 \mathrm{~mm}$; G: 20-22 days after hatching, mean $9.09 \mathrm{~mm}$ TL; H: 23-25 days after hatching, mean $9.67 \mathrm{~mm}$ TL; I: 30-32 days after hatching, mean $15.83 \mathrm{~mm}$ TL; J: 34-36 days after hatching, mean $16.58 \mathrm{~mm} \mathrm{TL}$; K: $43-45$ days after hatching, mean $22.50 \mathrm{~mm}$ TL. Scale bars $=1.0 \mathrm{~mm}$.

particularly clear between the first and fourth dorsal fin spiny rays. The stripes across the trunk took clearer shapes, and the caudal peduncle manifested one or two striped patterns. The caudal fin was more deeply concave in the center, and the ventral fin further elongated. Juveniles were covered with scales, and differentiation of the nostrils was completed (Fig. 3J).

The juveniles were 22.10-22.70 $\mathrm{mm}$ TL (mean, 22.50 $\mathrm{mm}, \mathrm{n}=10$ ) on days $43-45$ after hatching. They had reached sub-adult atage, as body shape and the distribution of black pigment spots and horizontal stripes $(n=7-8)$ completely resembled those of adult fish (Fig. 3K).

\section{DISCUSSION}

The average TL of newly hatched A. schlegeli larvae in our study was $2.04 \mathrm{~mm}$ (range, 1.90-2.11 mm), which differed from that reported by Kim (1970) at $1.57 \mathrm{~mm}$, and Fukuhara (1987) at $2.17 \mathrm{~mm}$. The size of newly hatched larvae is assumed to be related to the size of the fertilized egg. The size of A. schlegeli larvae as measured in our study was similar to that of Pagrus major in the same family Sparidae $[2.01 \pm 0.06 \mathrm{~mm}$ (Fukuhara, 1984), 2.0 $3.0 \mathrm{~mm}$ (Pyen \& Jo, 1982)], and Acanthopagrus latus [1.98-2.06 mm (Leu \& Chou, 1996)]. However, our larvae were smaller than those of Acanthopagrus sivicolus [2.15$2.39 \mathrm{~mm}$ (Tawada, 1986)], Sparus sarba [3.3 mm (Deane et al., 2003)], and Girella punctata [2.27-2.35 mm (Mito,
1957)] (Table 1), but larger than those of Gymnocranius griseus [1.48-1.50 mm (Suzumiu \& Hioki, 1978)] and Oplegnathus fasciatus [1.59-1.82 mm (Koh, 1992)].

Larvae hatched with a closed mouth and anus. A. schlegeli is a species with a low degree of differentiation compared with that of Cypselurus agoo agoo (Kim \& Park, 1987), Hyporhamphus sajori (Kim et al., 1984), and Cololabis saira (Yusa, 1960), which hatch from demersal eggs. The larval oil globule is located posterior to the yolk and anterior to the anus, which is different from the anteriorinferior positioning of Plectorhinchus cinctus (Kobayashi \& Iwamoto, 1984) and Gymnocranius griseus (Suzuki \& Hioki, 1978) and consistent with that of Girella punctata (Mito, 1957) and Dentex tumifrons (Oka et al., 1956). Pagrus major (Han \& Kim, 1999) has an oil globule in a similar location to that of $A$. schlegeli, but they differ in that they hatch with the anus open.

The number of larval myomeres was $20-22(6 \leq n \leq 8+$ 14) in our study, which was the same as that observed by Kim (1970), $10+12=22$, but less than $8+18=26$ of $A$. sivicolus (Tawada, 1986), 8-9 $+17-18=25-27$ and $9+$ $17-18=26-28$ of Pagrus major (Han \& Kim, 1999; Mito, 1963), $9+15=24$ of Gymnocranius griseus (Suzumiu \& Hioki, 1978), $10+17=27$ of Oplegnathus fasciatus (Koh, 1992), and $11+16=27$ of Girella punctata (Mito, 1957) (Table 1).

The transition from larvae to post-larvae is determined by the yolk absorption period after hatching and is the most important factor determining the feeding plan during the fish production cycle (Hansen \& Moller, 1985). The yolk absorption period varies depending on the species, habitat, and water temperature. In general, A. schlegeli requires about 5 days after hatching to complete yolk absorption (Kim, 1970), as demonstrated in our study (5-6 days).

A. sivicolus completes yolk absorption on day 4 after hatching (Tawada, 1986), Pagrus major completed yolk absorption 2-3 days (Fukuhara, 1984; Pyen \& Jo, 1982), 
Table 1. Comparison of prelarval characters in Sparidae and other species

\begin{tabular}{|c|c|c|c|c|}
\hline Species & $\begin{array}{l}\text { Water temperature } \\
\qquad\left({ }^{\circ} \mathrm{C}\right)\end{array}$ & Prelarva (mm) & Number of myotomes & References \\
\hline \multirow{6}{*}{$\begin{array}{c}\text { Acanthopagrus } \\
\text { schlegeli }\end{array}$} & $20.0-24.3$ & $1.90-2.11$ & $6-8+14=20-22$ & Present study \\
\hline & $21-28$ & 1.57 & $10+12=22$ & Kim (1970) \\
\hline & $12-20$ & $1.90-2.02$ & $9+17=26$ & Mito (1963) \\
\hline & 17.2 & $2.179 \pm 0.056$ & - & Fukuhara (1987) \\
\hline & $16.8-19.0$ & $19.8 \pm 0.13$ & $10+12=22$ & $\begin{array}{l}\text { Lee \& Rho } \\
\text { (1987) }\end{array}$ \\
\hline & - & - & $6+19=25$ & $\begin{array}{l}\text { Yamada et al } \\
\text { (2007) }\end{array}$ \\
\hline Acanthopagtrus latus & - & $1.98-2.06$ & - & $\begin{array}{l}\text { Leu \& Chou } \\
\quad(1996)\end{array}$ \\
\hline Sparus sarda & - & 3.3 & - & $\begin{array}{l}\text { Deane et al } \\
\text { (2003) }\end{array}$ \\
\hline \multirow{5}{*}{ Pagrsu major } & - & $2-3$ & - & Pyen \& Jo (1982) \\
\hline & 20 & $2.01 \pm 0.06$ & - & Fukuhara (1984) \\
\hline & 20 & 2.12 & $9+17-19=26-27$ & Mito (1963) \\
\hline & $22.5-23.0$ & $2.35-2.50$ & $\begin{array}{c}8-9+17-18 \\
=25-27\end{array}$ & $\begin{array}{l}\text { Han \& Kim } \\
\text { (1999) }\end{array}$ \\
\hline & 20 & $1.94-2.12$ & $9+17-18=26-28$ & Mito (1963) \\
\hline Oplegnathus fasciatus & 22.2 & $1.59-1.82$ & $10+17=27$ & Koh (1992) \\
\hline Girella punctata & $14-17$ & $2.27-2.35$ & $11+16=27$ & Mito (1957) \\
\hline Gymnocranius griseus & $20.0-22.4$ & $1.48-1.50$ & $9+15=24$ & $\begin{array}{c}\text { Suzumiu \& Hioki } \\
\text { (1978) }\end{array}$ \\
\hline
\end{tabular}

Acanthopagrus latus in 2-3 days (Leu \& Chou, 1996), and Sparus sarba in 7 days (Deane et al., 2003), demonstrating differences among genera and species in the same family. Furthermore, Girella punctata exhibits faster yolk absorption at 3 days (Mito, 1957), and Oplegnathus fasciatus was similar at 6 days (Koh, 1992). Such differences are assumed to result from accelerated yolk consumption as developmental speed and nutrient demands increase due to increased physiological activities in proportion to an increase in rearing water temperature (Heming, 1982).

The transition from post-larvae to juveniles is determined when all fins reach their full counts, and when band patterns resemble those of adult fish. In our experiment, juveniles began to show body shape and color similar to those of brood stock on days 30-32 after hatching. In comparison, the duration for A. sivicolus was 45 days (Tawada, 1986), that for Oplegnathus fasciatus was 37 days (Koh, 1992), and that for Acanthopagrus latus was 30-38 days (Leu \& Chou, 1996).

A, schlegeli larvae have very similar morphology to other species in the family Sparidae. However, Sparus sarba can be easily distinguished by the number of rays on 
the dorsal fin $(\mathrm{n}=23)$, anal fin $(\mathrm{n}=13)$, and regions where black pigment spots appear, such as the caudal peduncle. $A$. latus can be distinguished by the lack of melanophores at the base of dorsal fin I and the angle region. Additionally, its spawning season is October - January. A. sivicolus, A. berda, and $A$. australis can also be easily distinguished due to different habitats (south of Amami Oshima in Japan) (Senta \& Kinoshita, 1985). Among different Sparidae species, Dentex tumifrons is conspicuous because of its well developed spines at the outer margin of the preopercle, and Pagrus major and Evynnis cardinalis have higher body heights than that of A. schlegeli (Okiyama, 1988).

Some species show no evidence of melanophores until hatching, such as Hyporhamphus sajori (Kim et al., 1984). Similar to P. major (Han \& Kim, 1999), the heart of A. schlegeli begins to beat after black pigment spots appear on the body. Yamada et al. (2007) reported that a cluster of clear black pigment spots appears on the occipital crest at a TL of about $5.5 \mathrm{~mm}$. An additional cluster occurs in the dorsal digestive tract, large melanophores form inferior to the digestive tract, and about 10 melanophores align inferiorly to the caudal margin. In the present study, black pigment spots densely developed in the occipital crest and around the digestive tract both dorsally and ventrally, and about 12 black pigment spots were aligned ventrally along the caudal margin at a mean TL of $5.75 \mathrm{~mm}$ (Fig. 3E); thus, demonstrating generally similar regions for melanophores. The slight difference in the black pigment spots was assumed to be due to coagulation or loss of melanophores during sampling and storage rather than differences among regional communities. A Scorpaenidae species caught in China has a different number and shape of black pigment spots on the dorsal fin compared with those caught in Korea and Japan (Myoung et al., 1989). Thus, further study on A. schlegeli is necessary to determine the differences, if any, among regional communities by investigating the life cycles of individuals caught in various regions.

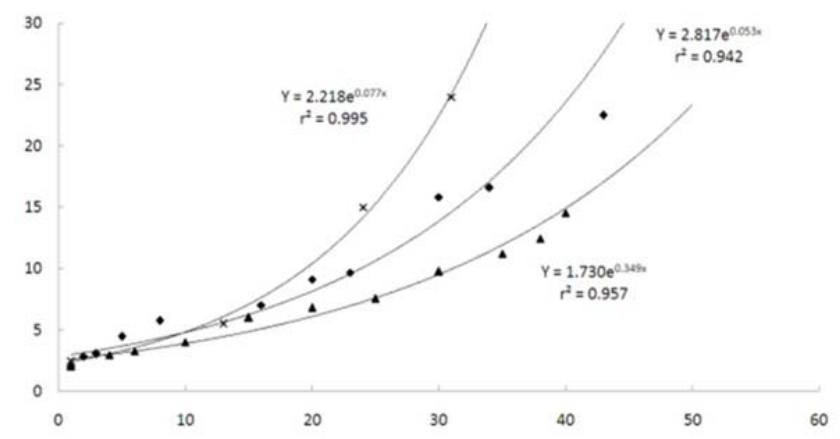

Fig. 4. Mean increase in total length $(\mathrm{cm})$ of Acanthopagrus schlegeli $(\diamond)$, Chrysophrys major $(\times)$, and Acanthopagrus latus $(\Delta)$ during the rearing experiment. $\diamond$, present study; ×, Pyen \& Jo (1982);

$\boldsymbol{\Delta}$, Leu and Chou (1996).

A. schlegeli had a slower grow rate than that of P. major $\left(\mathrm{Y}=2.817 \mathrm{e} 0.053 \mathrm{x}, \mathrm{r}^{2}=0.942\right.$ vs. $\mathrm{Y}=2.218 \mathrm{e} 0.077 \mathrm{x}, \mathrm{r}^{2}=$ $0.995)$ but faster than that of A. latus $\left(\mathrm{Y}=1.730 \mathrm{e} 0.349 \mathrm{x}, \mathrm{r}^{2}\right.$ $=0.957$ ) from day 1 after hatching (Leu \& Chou, 1996; Pyen \& Jo, 1982).

Taken together, these results show that $A$. schlegeli have a slightly slower growth rate during the early stages compared with that of other species in the same family. Growth experiments should be conducted under different rearing conditions based on water temperature.

\section{ACKNOWLEDGEMENT}

This research was supported by Basic Science Research Program through the National Research Foundation of Korea (NRF) funded by the Ministry of Education, Science and Technology (2011-0011204).

\section{REFERENCES}

Akazaki M, Tokito A (1982) Studies on the seedling production of yellowfin porgy (Kichinu), Acanthopagrus latus Houttuyn-II Eg development and metamorphoses of larvae. Aquacult 29:218-228. 
Chyung MK (1977) The Fishes of Korea. Iljisa, Seoul, $777 \mathrm{pp}$.

Deane EE, Kelly SP, Collins PM, Woo NYS (2003) Larval development of Silver sea bream (Sparus sarba): ontogeny of RNA-DNA ratio, GH, IGF-I, and $\mathrm{Na}^{+}-\mathrm{K}^{+}$ATPase. Mar Biotechnol 5:79-91.

Fukuhara O (1977) Some morphological observation on larvae and juveniles of the Kurodai, Mylio macrocephalus (Sparidae: TELEOSTEI) reared in the laboratory. Bull Nansei Reg Fish Res Lab 10:1-16.

Fukuhara O (1984) Morphological studies of larva of Red sea bream-IV. Morphological development and early growth. Bull Namsei Reg Fish Res Lab 16:85-94.

Fukuhara O (1987) Larval development and behavior in early life stages of Black sea bream reared in the laboratory. Nippon Suisan Gakkaishi 53:371-379.

Han KH, Kim YU (1999) Eggs development and morphology of larvae of the sea bream, Pagrus major. J Institute for Basic Sciences Yosu Nat Univ 1:65-74.

Hansen TT, Moller D (1985) Yolk absorption, yolk sac constriction, mortality, and growth during first feeding of Atlantic salmon (Salmo salar) incubated on astroturf. Can J Fish Aquat Sci 42:1073-1078.

Heming TA (1982) Effects of temperature on utilization of yolk of by chinook salmon (Oncorhynchus tshawytscha) egg and alevins. Can J Fish Aquat Sci 39:184-190.

Ji SC, Yoo JH, Jeong GS, Myoung JG, Lee SW, Go HJ (2004) Comparison of digestive organ and body composition among the cultured, wild and released fish, 1year Black sea bream (Acanthopagrus schlegeli). J Korean Fish Soc 37:462-468.

Ji SC, Lee SW, Yoo JH, Kim YS, Jeong GS, Myoung JG (2007) Initial feeding habits and changes in body composition of juvenile Black sea bream, Acanthopagrus schlegeli released into the Gamak bay. J Aqua 20:9095.

Kang KM, Shin HO, Kang DH, Kim MS (2008) Comparison of behavior characteristics between wild and cultured black seabream Acanthopagrus schlegeli using acoustic telemetry. Bull Korean Soc Fish Tech 4492:141-147.

Kim YU (1970) On the characteristics of eggs and larva of Mylio macrocephalus (Basilewsky). Bull Korean Fish Soc 3:233-250.

Kim YS, Han KH, Kang CB, Kim JB (2004) Commercial Fishes of the Coastal and Offshore Waters in Korea. 2nd ed. Hangul, Busan, Korea. 333pp.

Kim YU, Myoung JG, Choi SO (1984) Eggs development and larvae of the horn fish, Hemiramphus sajori Temminck et Schlegel. Bull Korean Fish Soc 17:125131.

Kobayashi T, Iwamoto T (1984) Early life history of the threebanded sweetlip, Plectorhynchus cinctus. Japan J Ichthyl 30:412-418.

Koh JN, Kim UK (1992) Embryonic development and morphology of larvae and juveniles of parrot fish, Oplegnathus fasciatus (Temminck et Schlegel). Bull Nat Fish Univ Pusan 32:29-45.

Lee JJ, Rho S (1987) Studies on the seding production of the black porgy Acanthopagrus schlegeli. Bull Mar Resour Res Inst Cheju Nat Univ 11:1-20.

Lee JS, Kim HY, Byun SG, Kim JD, Go CS, Chin P (2000) Ontogeny of the digestive organ during early life stages of the Black sea bream, Acanthopagrus schlegeli (Teleostei: Sparidae). J Korean Fish Soc 33:129-136.

Leu MY, Chou YH (1996) Induced spawning and larval rearing of captive yellowfin porgy, Acanthopagrus latus (Houttuyn). Aquaculture 143:155-166.

Mito S (1957) Eggs development and hatched larvae of Girella punctata gray. Japan J Ichthyol 6:105-108.

Mito S (1963) Pelagic fish eggs from Japanese waters-III. Japan J Ichthyol 11:39-57.

Myoung JG, Kim JM, Kim YU (1989) Egg development and morphology of larvae of South sea devil stinger Inimicus japonicas (Cuvier et Valenciennes) reared in 
the aquarium. Korean J Ichthyol 1:1-8.

Oka M, Aoyama T, Kawasaki T (1956) On the development of the egg of Taius tumifrons. Japan J Ichthyol 5: 61-64.

Okamura O, Amaoka K (1997) Sea Fishes of Japan. Yama-kei Publishers Co., Ltd. Tokyo, Japan. 783pp.

Okiyama M (1988) An Atlas of the Early Stage Fishes in Japan. Tokai Univ. Press, Tokyo, 1154pp.

Oshima T (1942) Studies on ecology of black porgy Acanthopagrus schlegeli. Bull Jap Soc Sci Fish 10: 249-255.

Park SW, No YS, Yu JH, Kim JD (2008) Vertebral abnormality in hatchery-reared Black sea bream (Acanthopagrus schlegeli) fingerlings. J Fish Path 21:139-148.

Park YS, Kim YU (1987) Studies on the larvae and juveniles of flying fish, Prognichthys agoo (Temminck and Schlegel) (Pisces, Exocoetidae) I. Development of eggs, larvae and juveniles. Bull Korean Fish Soc 20: 308-316.
Pyen CK, Jo JY (1982) Seed production of sea-bream, Chrysophrys major. Bull Korean Fish Soc 15:161-170.

Senoo H (1912. Development of black porgy Acanthopagrus schlegeli. Zool Mag 24:195-197.

Senta T, Kinoshita I (1985) Larvae and juvenile fishes occurring in surf zones of western Japan. Trans Am Fish Soc 114:609-619.

Suzumizu K, Hioki K (1978) Spawning behavior, egg, and juvenile of naked head large eye bream Gymnocranius griseus observed in the aquarium. Japan. J Ichthyol 24: 271-277.

Yoo JH, Hwang DJ, Yoon YH, Jeong GS (2003) Initial adaptation of released Black sea bream, Acanthopagrus schlegeli in Gamak bay, southern coast in Korea. J Korean Fish Soc 36:356-371.

Yusa T (1960) Embryonic development of the saury, Cololabis saria (BREVOORT). Bull Tohoku Reg Fish Res Lab 17:1-13. 